\title{
Numerical Analysis of Tip Vortex and Cavitation of Elliptic Hydrofoil with NACA 66-415 Cross Section
}

\author{
Il-Ryong Park ${ }^{\circledR *}$, Je-in Kim*, Han-Sin Seol ${ }^{* * *}$, Ki-Sup Kim ${ }^{* * *}$ and Jong-Woo Ahn ${ }^{* * *}$ \\ "Department of Naval Architecture and Ocean Engineering, Dong-Eui University, Busan, Korea \\ ${ }^{*}$ Marine Hydrodynamic Performance Research Center, Dong-Eui University, Busan, Korea \\ ${ }^{*}$ Korea Ocean Research \& Development Institute, Korea research Institute of Ship E Ocean Engineering, Daejeon, Korea
}
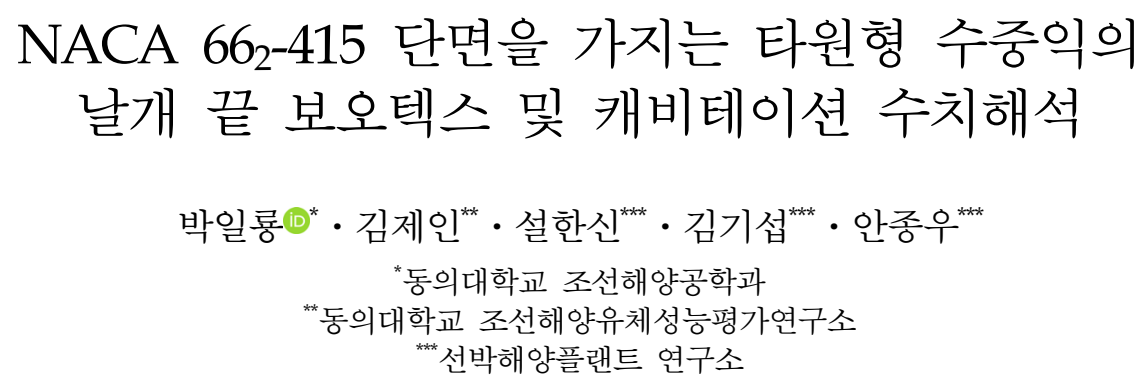

KEY WORDS: Elliptic hydrofoil 타원형 수중익, CFD 전산유체역학, Tip vortex cavitation 날개 끝 보오텍스 캐비테이션, Local flow analysis 국부유동해석, Turbulence model 난류모형

\begin{abstract}
This paper provides quantification of the effects of the turbulence model and grid refinement on the analysis of tip vortex flows by using the RANS(Reynolds averaged Navier-Stokes) method. Numerical simulations of the tip vortex flows of the NACA 66-415 elliptic hydrofoil were conducted, and two turbulence models for RANS closure were tested, i.e., the Realizable $k-\varepsilon$ model and the Reynolds stress transport model. Numerical results were compared with available experimental data, and it was shown that the data for the Reynolds stress transport model that were computed on the finest grid system had better agreement in reproducing the development and propagation of the tip vortex. The Realizable $k-\varepsilon$ model overestimated the turbulence level in the vortex core and showed a diffusive behavior of the tip vortex. The tip vortex cavitation on the hydrofoil and its trajectory also showed good agreement between the current numerical results that were obtained using the Reynolds stress transport model and the results observed in the experiment.
\end{abstract}

\section{1. 서 론}

선박 및 잠수함의 프로펠러에서 발생하는 캐비테이션은 프로 펠러의 성능 저하의 원인이 되며 변동압력 증가로 인한 승선감 감소와 프로펠러 침식의 문제를 발생시킨다. 또한, 선박의 추진 기와 캐비테이션으로 인한 소음은 수중 생물들에게 큰 영향을 미치는 것으로 밝혀져 현재 국제법으로 선박의 소음을 규제할 예정인 것으로 알려져 있다. 수상함정 및 잠수함의 측면에서 캐 비테이션 소음은 작전 중 함정의 기밀성을 손상시키는 큰 원인 이 되고 있다. 따라서, 설계단계에서부터 모형시험이나 수치해 석을 통해 캐비테이션 발생에 대한 문제를 파악하고 이를 해결 하기 위한 많은 연구들이 수행되고 있다(Ahn et al., 2001; Seol et al., 2004; Lee et al., 2007; Choi et al., 2007; Lee et al., 2010b; Kang et al., 2014).

일반적으로 실선 프로펠러에서는 날개 끝 보오텍스 캐비테이 션(Tip vortex cavitation)이 가장 먼저 발생한다. 이때 날개 끝에서 발생하는 강한 보오텍스를 중심으로 형성되는 매우 낮은 압력장 으로 인해 캐비테이션이 생기고, 이후 소음이 급증하여 주 소음 원이 된다(Lee et al. 2010a). 특히, 생존성이 중요한 함정이나 잠 수함의 경우 날개 끝 캐비테이션 방사소음을 제어하고 캐비테이 션 초생속도(Cavitation inception speed)를 높이기 위한 실험 및 수 치 해석적 연구의 노력들이 필요하다. 날개 끝 보오텍스 캐비테 이션에 집중한 관련된 연구들의 예로서, 소음해석을 포함한 수치 해석적 연구가 Park(2004)과 Park et al.(2006)에 의해 수행되었고

Received 1 August 2018, revised 18 August 2018, accepted 20 August 2018

Corresponding author Il-Ryong Park: +82-051-890-2595, irpark@deu.ac.kr ORCID: https://orcid.org/0000-0002-6194-5716

(C) 2018, The Korean Society of Ocean Engineers

This is an open access article distributed under the terms of the creative commons attribution non-commercial license (http://creativecommons.org/licenses/by-nc/3.0) which permits unrestricted non-commercial use, distribution, and reproduction in any medium, provided the original work is properly cited. 
이를 제어하는 방법에 대한 실험적 연구가 Lee et al.(2010a)에 의 해 수행된 바 있다. Arndt et al.(1991)과 Peng et al.(2017)은 타원형 수중익(Elliptic hydrofoil)에 대한 날개 끝 보오텍스의 물리적 특성 과 캐비테이션 현상을 실험으로 연구하였다.

본 논문에서는 타원형 수중익에서 발생하는 날개 끝 보오텍 스와 캐비테이션 연구를 위해 전산유체역학(Computational fluid dynamics, CFD)기법을 적용한 결과를 소개하고 있다. 수치해석 기법은 RANS(Reynolds averaged Navier-Stokes)법에 한정하고 대 상 유동의 평균 특성(Mean property)을 해석하였다. 연구의 내용 은 주로 날개 끝 보오텍스의 해석 정도를 높이기 위한 격자계 와 난류모형의 의존성을 검토한 결과와 실험결과를 이용한 수 치해석 검증을 포함한다. 또한, 기존 실험과 수치해석 연구들에 서 알려진 수중익 날개 끝 보오텍스와 캐비테이션의 물리적 특 성들을 바탕으로 본 $\mathrm{CFD}$ 해석 결과들의 물리적 타당성을 검토 하고 논의하였다.

\section{2. 수치 해석 방법}

본 논문의 모든 수치해석은 범용프로그램 STAR-CCM+ (Siemens, 2016)를 이용하여 수행하였다. 관련된 수치해석 기법을 간략히 소 개하면 다음과 같다. 유동은 완전히 발달된 난류 유동(Turbulent flow)으로 가정하여 연속 방정식과 운동량 보존 방정식인 RANS 방정식이 유동의 지배방정식이 된다. 지배방정식의 해는 유한체 적법(Finite volume method)으로 구해지며 시간 적분 및 공간에 대해 2 차 정도의 수치 이산화 기법이 사용되었다. 여기서, 비압축 성 유동 해석 시 요구되는 유체의 속도와 압력을 연성하는 방법 으로 SIMPLE(Semi-implicit method for pressure-linked equation) 방 법을 이용하였다.

난류모형은 Realizable k- $\varepsilon$ 모형(이하 RKE)과 Reynolds stress $\operatorname{model}($ 이하 RSM)을 각각 도입하고 수치해석 결과에서 이들의 결과들을 서로 비교하였다. 여기서, RKE 난류모형은 RANS 방 정식에 나타나는 Reynolds응력(Stress)항을 평균유속의 구배와 Reynolds응력의 관계를 나타내는 Boussinesq가설을 도입하여 난 류운동에너지(Turbulent kinetic energy)와 난류소산율(Turbulence dissipation rate)의 2 개의 방정식에서 와점성모델(Eddy viscosity model)로 처리하는 방법들 중 하나이다. 반면, RSM 난류모형은 상기 2개의 난류방정식과 함께 Reynolds응력항을 7 개의 수송방 정식으로 모델링하여 직접적으로 해석하는 방법으로 비등방성 의 복잡한 유동 해석에 적합하다.

수중익 날개 끝에서 발생하는 날개 끝 보오텍스 캐비테이션 현 상은 단순화된 Rayleight-Plesset방정식을 기반으로 만들어진 Sauer (2000)가 제시한 캐비테이션 모델을 이용하여 해석하였다. 여기 서, 캐비테이션 유동을 해석할 경우 고려해야 할 이상유동(Twophase flow)은 VOF(Volume-of-fluid)법을 이용하여 처리된다.

\section{3. 수치 해석 결과}

\section{1 타원형 수중익 및 해석조건}

본 논문의 수치해석 대상이 되는 수중익은 날개 끝 캐비테이션 연구를 위해 Arndt et al.(1991)가 실험한 NACA(National Advisory

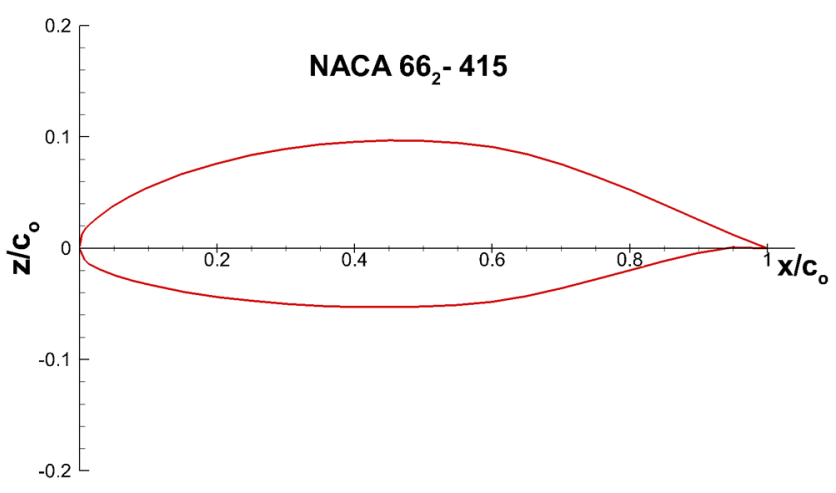

Fig. 1 NACA $66_{2}-415$ section

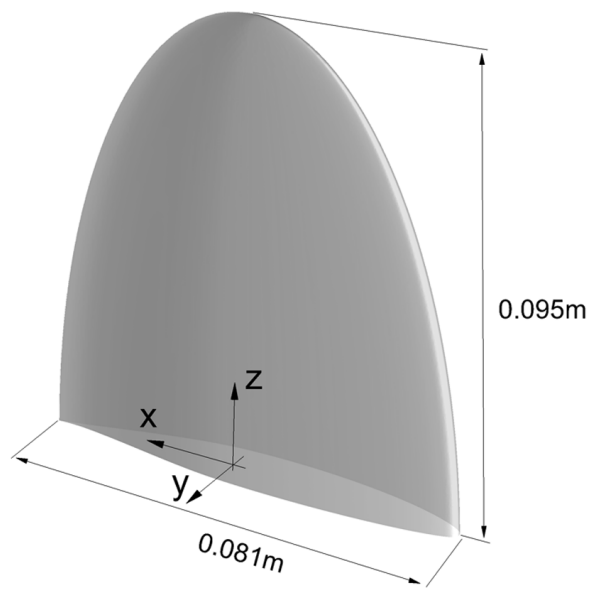

Fig. 2 NACA $66_{2}-415$ Elliptic hydrofoil

Committee for Aeronautics) $66_{2}-415$ 날개 단면의 반타원형 수중 익이다. 수중익의 단면 형상과 수중익의 주요 치수를 기입한 3 차원 형상은 각각 Fig. 1과 Fig. 2에 각각 나타내었다. Fig. 2에서 볼 수 있듯이 좌표계는 수중익의 코드길이(Chord length, $c_{o}$ ) 방 향을 $x$, 수중익의 압력면(Pressure side)을 양의 $y$ 축 그리고 중력 작용의 반대 방향을 양의 $z$ 축으로 두었다. 수중익 바닥면의 코 드길이는 $0.081 \mathrm{~m}$ 이며 스팬길이(Span length, $b$ )는 $0.095 \mathrm{~m}$ 이다. 캠버(Camber)가 있는 본 날개 단면의 입사각(Angle of attack)은 양력이 영인 입사각이 $\alpha_{o}$ 일 때 다음과 같이 정의된다.

$$
\alpha_{e f f}=\alpha-\alpha_{o}
$$

여기서, NACA $66_{2}-415$ 단면의 양력이 영인 입사각은 이론값의 약 $75 \%$ 인 실험을 통해 얻어진 $\alpha_{0}-2.5^{\circ}$ 값을 사용하였다(Arndt et al., 1991). 본 논문에서 계산된 수치해석 조건은 Table 1에 정리 하여 나타내었다. 해석조건 Case 1과 Case 2는 수중익 날개 끝 의 국부유동에 대한 해석조건이며, Case 3 은 날개 끝 캐비테이 션을 해석하기 위한 조건이다. 표에서 $R_{n}$ 은 수중익의 코드길이 에 대한 Reynolds수, $U_{\infty}$ 는 유입 경계면에서 유속을 나타내고 $\sigma$ 는 캐비테이션수로서 다음과 같다.

$$
\sigma=\frac{p_{r e f}-p_{v}}{0.5 \rho U_{\infty}^{2}}
$$


Table 1 Test conditions for non-cavitating and cavitating flows

\begin{tabular}{cccc}
\hline \hline & Case 1 & Case 2 & Case 3 \\
\hline$R_{n}$ & $5.2 \times 10^{5}$ & $4.7 \times 10^{4}$ & $5.3 \times 10^{5}$ \\
$U_{\infty}[\mathrm{m} / \mathrm{s}]$ & 6.50 & 0.59 & 6.62 \\
$\alpha_{e f f}$ & $12^{\circ}$ & $12^{\circ}$ & $9.5^{\circ}$ \\
$\sigma$ & - & - & 1.15 \\
\hline
\end{tabular}

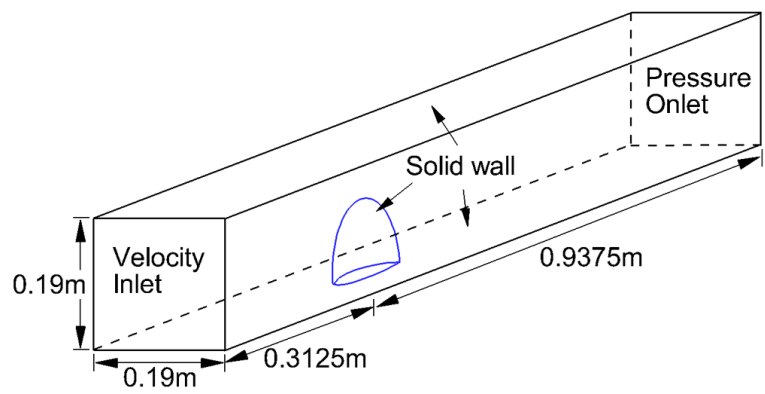

Fig. 3 Flow domain and boundary conditions

여기서, $p_{r e f}$ 와 $p_{v}$ 는 수중익 주위 유체의 압력과 주어진 온도에 대한 증기압력(Vapour pressure)을 각각 나타내고 $\rho$ 는 유체의 밀 도이다.

수치해석은 실험과 같은 조건의 유동장에서 수행되었으며, 이 때 유동장은 Fig. 3 과 같이 한 변이 $0.19 \mathrm{~m}$ 인 정사각 단면을 가 지며 총 길이는 날개 중심에서 상류 방향으로 $0.3125 \mathrm{~m}$, 하류 방 향으로 $0.9375 \mathrm{~m}$ 이다. 여기서, 유동장의 상류 경계면은 유속유입 조건(Velocity inlet), 하류 경계면은 압력유출조건(Pressure outlet), 측면 및 상하면 그리고 수중익은 고체 경계면(Solid wall)조건을 적용하였다. 유동장 내 밀도(Density)는 $\rho=998.261 \mathrm{~kg} / \mathrm{m}^{3}$, 운동학 적 점성계수(Kinematic viscosity)는 $\nu=1.01 \times 10^{-6} \mathrm{~m}^{2} / \mathrm{s}$ 이다.

수치해석은 Table 2 와 같이 총 세 가지 격자계에서 수행되었 으며 가장 조밀한 격자계(Fine grid)의 격자수를 약 10.0 백만(M) 개로 두고 격자 간 약 2 배의 격자수 비율을 유지하도록 하였다. 중간 격자계(Medium grid)의 격자수는 약 $5.0 \mathrm{M}$ 개, 가장 성긴 격 자계(Coarse grid)는 $2.5 \mathrm{M}$ 개이다. 세 가지 격자계 모두 동일하게 벽면에서 첫 번째 격자까지의 무차원 거리 $y^{+} \approx 1$ 을 유지하도록 설정하였다. 한편, 날개 끝 보오텍스 거동해석에 있어 보오텍스 주위 격자 요소의 크기(Grid cell size)가 충분히 작지 않을 경우, 사용한 수치 이산화 기법과 난류모형의 오차들의 영향과 함께 보오텍스의 발달과 하류로 전파되는 상황을 정확하게 해석할 수 없다(Kim et al., 2017). 이러한 이유로 본 논문에서는 Fig. 4 와 같이 날개 끝에서부터 날개 끝 보오텍스 발생 영역을 따라 다른 영역보다 좀 더 조밀하게 등간격의 격자를 좌표계 모든 방향으로 집중하였다. 이러한 격자의 집중은 사전 해석을 통해

Table 2 Grid characteristics

\begin{tabular}{cccc}
\hline \hline & No. of grids & $y^{+}$ & $\begin{array}{c}\text { Grid cell size around } \\
\text { tip vortex }\end{array}$ \\
\hline Coarse grid & $2.5 \mathrm{M}$ & 1 & $0.28 \mathrm{~mm}$ \\
Medium grid & $5.0 \mathrm{M}$ & 1 & $0.20 \mathrm{~mm}$ \\
Fine grid & $10.0 \mathrm{M}$ & 1 & $0.15 \mathrm{~mm}$ \\
\hline
\end{tabular}

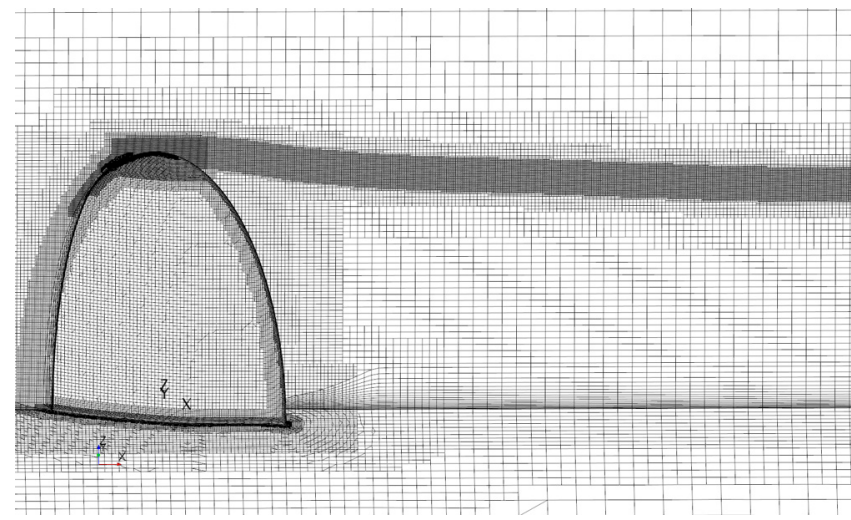

(a) Surface grid and grid adaptation

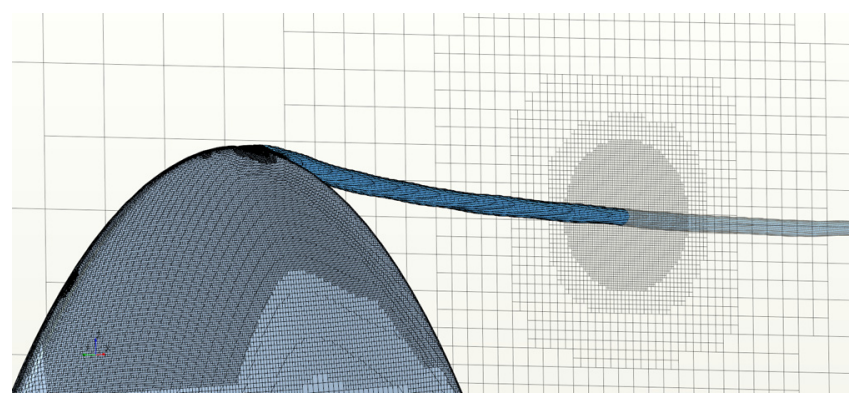

(b) Grid refinement around tip vortex

Fig. 4 Grid characteristics around the elliptic hydrofoil

날개 끝 보오텍스의 위치를 확인하고 유동장 하류 방향으로 격 자 집중 영역을 확장하는 방법을 사용하였다. 날개 끝 보오텍스 해상도를 높이기 위해 사용된 격자 요소의 크기는 Table 2에 정 리하여 나타내었다.

\section{2 타원형 수중익 후류 국부유동 해석}

본 절에서는 난류모형과 격자계가 타원형 수중익 날개 끝에 서 발생하는 보오텍스 거동 변화에 미치는 영향을 비교하고 실 험에서 계측된 평균유속 데이터를 통해 검증한 내용을 소개한 다. 더불어 알려진 수중익 후류의 자유 전단 회전유동(Free shear vortical flow)에 대한 본 수치해석 결과의 물리적 타당성을 검토하였다. 대상 타원형 수중익 날개 끝 국부유동에 대한 수치 해석은 앞서 Table 2에 나타낸 Case 1과 Case 2의 Reynolds수에 서 계산되었으며, 유입 유속은 각각 $6.50 \mathrm{~m} / \mathrm{s}$ 와 $0.59 \mathrm{~m} / \mathrm{s}$ 이다. 유 효 입사각은 $12^{\circ}$ 로 동일하며 Case 1 의 경우 RSM과 RKE 난류모 델을 사용하여 비교하였고, Case 2의 경우 가장 조밀한 격자계 에 대해 RSM 난류모형만으로 해석하였다.

Fig. 5는 대상 수중익의 압력면을 바라보는 관점에서 날개 끝 에서 하류 방향으로 날개 끝 보오텍스를 따라 후처리를 위해 위치시킨 제한된 폭과 높이의 단면들 내 와도의 크기(Vorticity magnitude)를 나타내고 있다. 그림은 가장 조밀한 격자계의 결 과를 비교하고 있다. RKE 난류모형의 결과는 수중익의 하류로 가면서 보오텍스 중심(Vortex core) 영역의 와도의 크기가 점차 로 감소하고 더 먼 하류에서 중심 위치는 확인할 수 있지만, 그 강도가 유지되지 못하고 주류(Main flow)와의 상호작용으로 주 위로 확산되고 있다. 반면 RSM 난류모형은 수중익 하류 멀리까 


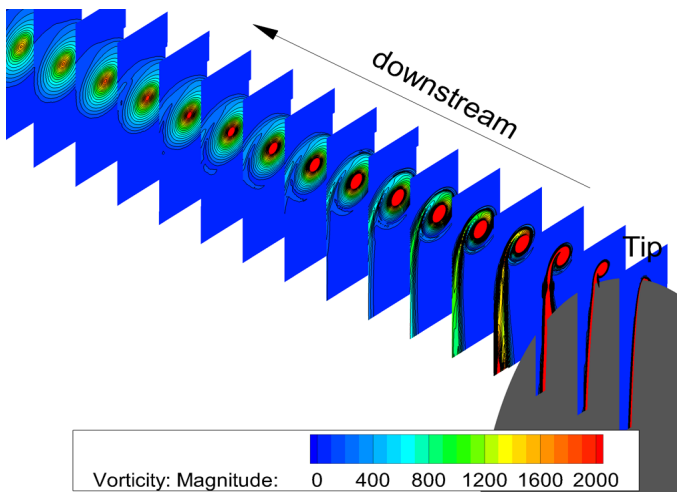

(a) RKE

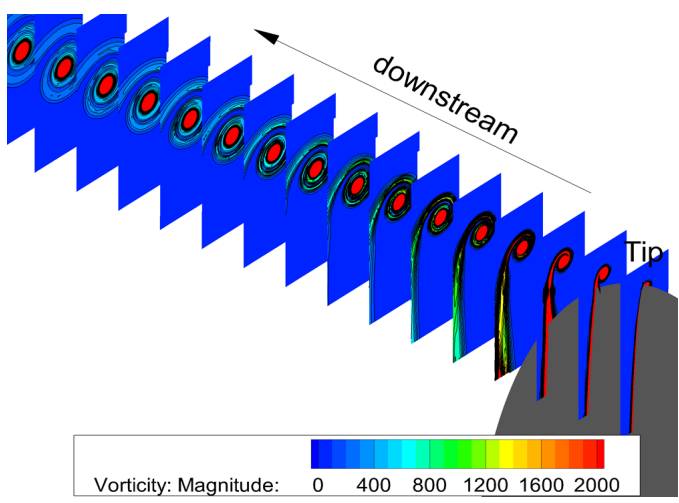

(b) RSM

Fig. 5 Comparison of vorticity magnitude

지 와도의 높은 값을 가지는 영역이 유지되는 것을 볼 수 있다.

Fig. 6와 Fig. 7은 같은 단면들에서 주류 방향인 $x$ 방향 유속 $(u)$ 과 $z$ 방향 유속 $(w)$ 분포를 각각 비교하고 있다. 날개 끝에서 발생하는 보오텍스가 수중익의 뒷날(Trailing edge)에서 발생한 2차 유동들과 상호작용하며 하류로 흘러가는 현상을 볼 수 있 다. 앞서 와도 강도와 마찬가지로 수중익 하류에서 RKE 난류모 형으로 얻은 두 유속 분포는 보오텍스 중심 주위로 다소 확산 되어 있고 유속의 크기도 감소하는 것을 볼 수 있다. 날개 끝 보오텍스 흐름의 특징 중 하나로 보오텍스 내부에서 주류인 $x$ 축 방향의 유속이 낮아지는 현상이 발생한다(Ragab and Sreedhar, 1995; Zeman, 1995). 이러한 축방향 속도손실(Velocity deficit)은 Fig. 6(b)의 RSM의 결과와 같이 날개 끝 보오텍스가 발달될 때 날개 끝에서부터 곧바로 발생하지 않는 것으로 알려져 있다. 주 류가 수중익 날개 끝을 지나면서 그 교란으로 발달되는 회전유 동이 점차 하류로 흐르면서 회전이 강하고 안정된 날개 끝 보 오텍스를 완전히 발달시킬 때까지 축방향 속도손실도 같은 과 정에서 점차적으로 증가한다. 이후 수중익 하류로 흘러가는 안 정화된 날개 끝 보오텍스를 따라 그 중심에서 축방향 속도손실 은 일정한 값을 유지한다(Ragab and Sreedhar, 1995). RKE 난류 모형의 결과는 속도손실이 날개 끝에서 바로 발생하고 있고 하 류로 가면서 속도손실이 오히려 감소하고 있다. 또한 $x$ 축 방향 속도분포에서 확인할 수 있는 보오텍스의 반경이 증가하는 수 치 확산이 다소 큰 결과를 보여주고 있다. 이러한 날개 끝 보오 텍스 내 속도손실은 다음 식으로 정의한다.

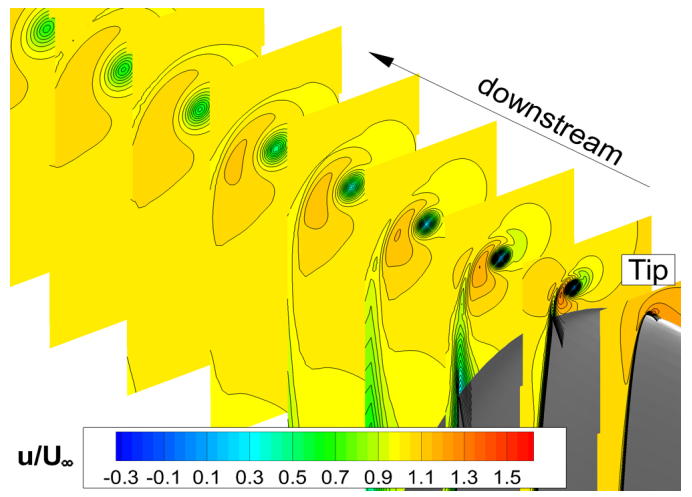

(a) RKE

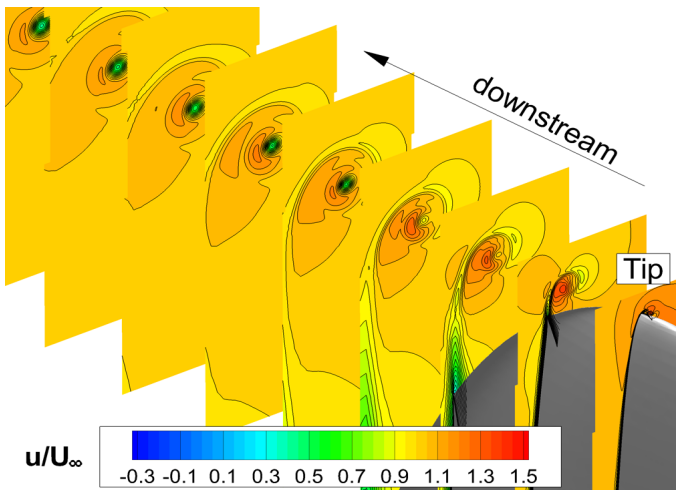

(b) RSM

Fig. 6 Comparison of axial velocity $(u)$

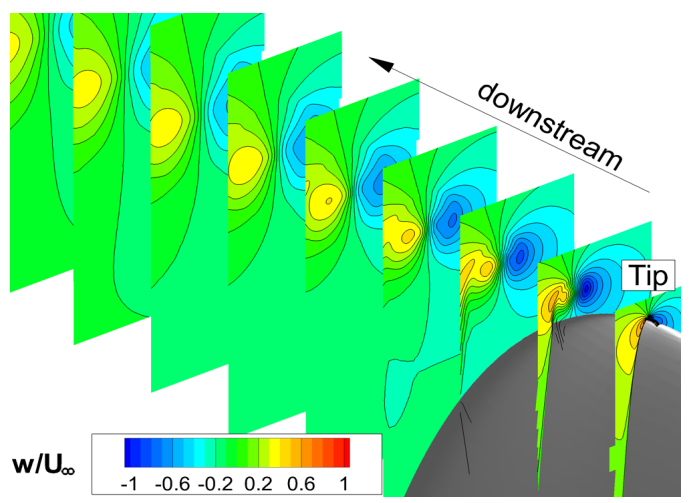

(a) RKE

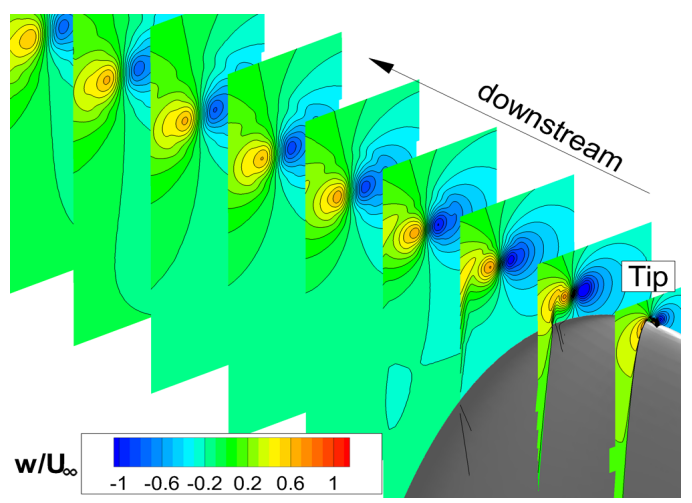

(b) RSM

Fig. 7 Comparison of vertical velocity $(w)$ 


$$
U_{D}=-\frac{u-U_{\infty}}{U_{\infty}}
$$

Fig. 8 은 $x / c_{o} 1.0$ 인 위치에서 $U_{D}$ 값을 비교하고 있으며 앞서 설명한 난류모형의 차이와 격자 해상도의 차이를 볼 수 있다. 여기서, $U_{D}$ 값이 크면 속도손실이 크다는 것을 나타낸다. 앞서 Fig. 2에 나타낸 좌표계 정의에 의해 그림의 음의 $y$ 축은 흡입면 (Suction side)이며 그 반대는 압력면이다. 격자 해상도의 영향을 살펴볼 때, 날개 끝 보오텍스의 반경 크기는 RSM 난류모형을 사용한 세 가지 격자계의 결과에서 비슷하게 예측되나 격자수 가 작은 격자계들에서 속도손실이 과소평가되고 있는 것을 볼 수 있다. Arndt et al.(1991)의 실험에서는 이러한 날개 끝 보오텍 스 내 속도손실을 계측하지 않아 비교를 못하였지만, NACA0012 날개에 대한 실험과 수치해석 결과를 비교한 Wells(2009)의 연 구결과를 참조할 때 본 수치해석 결과에서 보이는 물리적 현상 이 타당한 것을 확인하였다.

Fig. 9에서는 수중익 중심에서부터 $x / c_{0} 1.0$ 인 위치에서 보오텍 스 중심 주위 $z$ 방향의 속도분포를 실험 계측결과와 비교하고

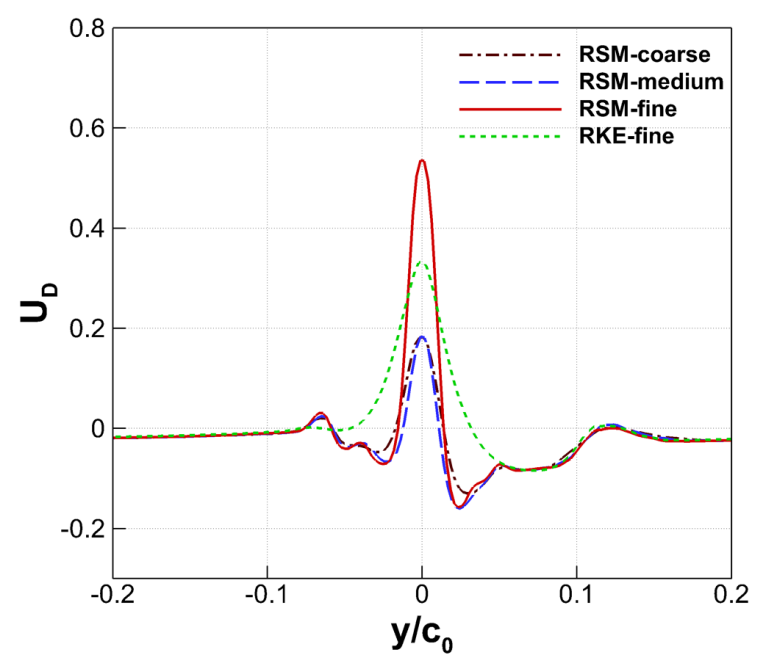

Fig. 8 Comparison of axial velocity deficit

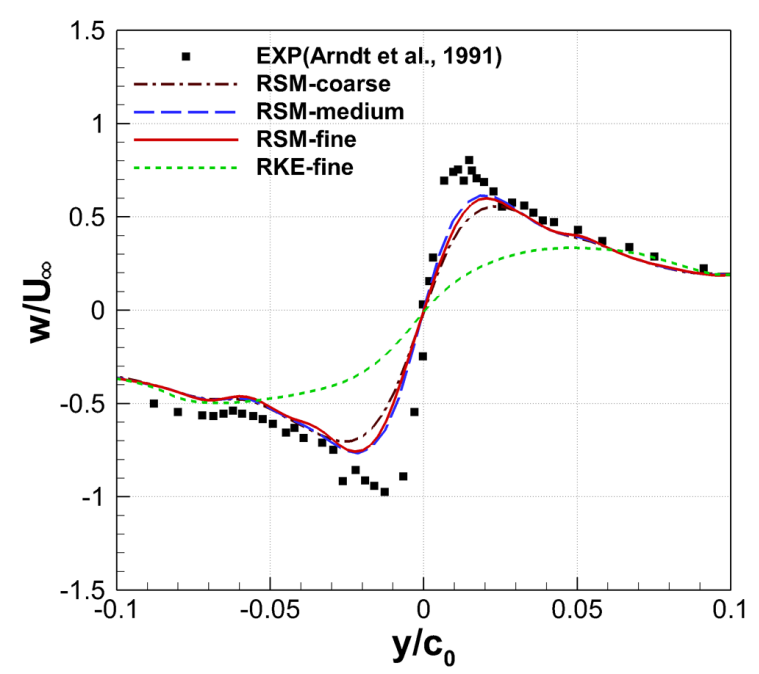

Fig. 9 Comparison of vertical velocity profile

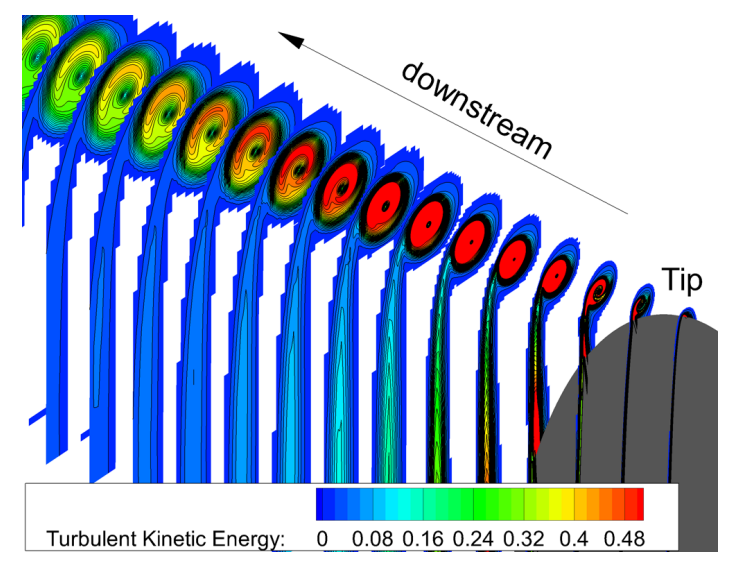

(a) RKE

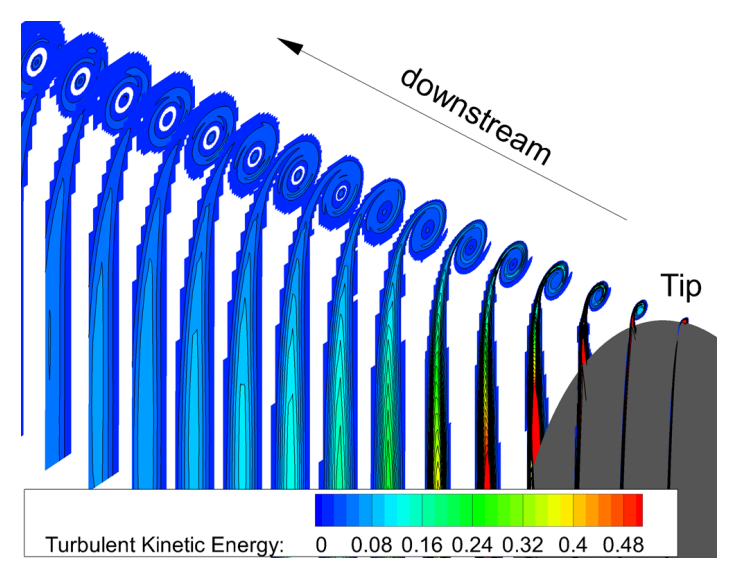

(b) RSM

Fig. 10 Comparison of turbulent kinetic energy

있다. 이후, 실험은 $\operatorname{EXP(Experiment)ㄹㅗ~ㅍㅛㄱㅣㅎㅏㅇㅕㅆㄷㅏ.~Fig.~8ㅇㅢ~ㅅㅗㄱ~}$ 도손실의 결과에서 볼 수 있었듯이, 그림에서 흡입면의 $z$ 방향 의 유속의 크기가 더 큰 유동의 비대칭 특성을 보여주고 있다. 앞서 설명한 바와 같이 RKE의 결과는 실험결과와 많은 차이를 보여주고 있지만, RSM 난류모형은 세 가지 격자계에서 유동의 비대칭성 및 유속의 크기에 대해 상대적으로 좋은 일치를 보여 주는 것을 확인할 수 있다. 그러나 실험 속도분포의 최대값과 최소값과는 다소 차이가 있는 것을 볼 수 있다. 이러한 차이를 감소시키기 위해서는 적절한 난류모형의 사용과 함께 격자 해 상도를 더 증가시키고 2 차 이상의 고차 이산화 기법을 사용해 야 하는 것으로 관련 연구 동향을 통해 알 수 있었다(DaclesMariani, 1999; Egolf, 2000; Wells, 2009).

Fig. 5에서부터 설명되고 있는 타원형 수중익의 날개 끝 보오 텍스 유동에 대한 난류모형의 차이의 원인은 Fig. 10에 나타낸 난류운동에너지(Turbulent kinetic energy) 분포로 설명될 수 있 다. Zeman(1995)과 Devenport et al.(1996)은 회전이 안정화된 날 개 끝 보오텍스가 완전히 발달될 때 보오텍스 내부는 난류생성 률(Turbulence production rate)이 거의 영에 가깝고 난류에너지가 주위보다 낮은 값을 갖는 것을 확인하였다. 이러한 현상을 보오 텍스 내부 유동의 층류화(Laminarization)로 설명하였다. 이러한 사실을 바탕으로 볼 때 RKE 모형의 경우 날개 끝 보오텍스 중 심 영역의 난류에너지가 주위보다 오히려 매우 큰 값을 보여주 고 있으며, RSM의 결과는 날개 끝에서 하류 방향으로 보오텍스 


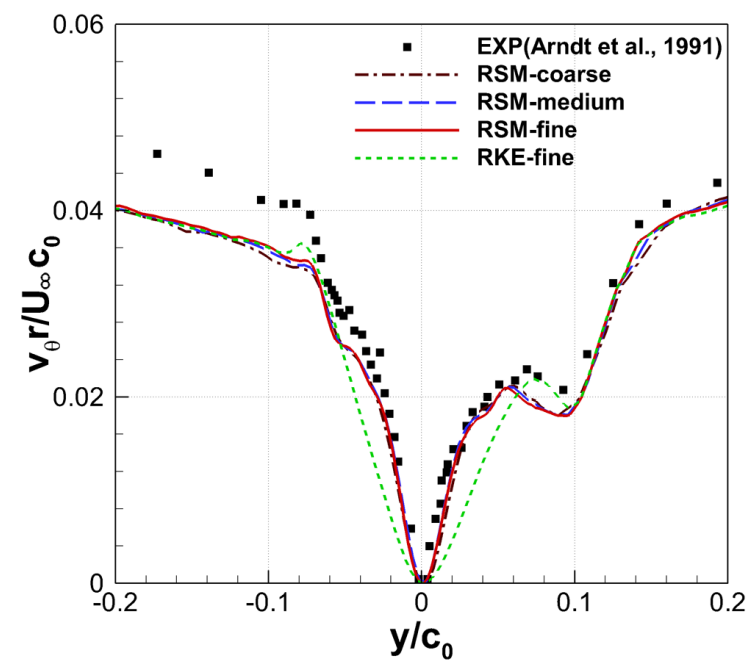

(a) Grid and turbulence model dependencies

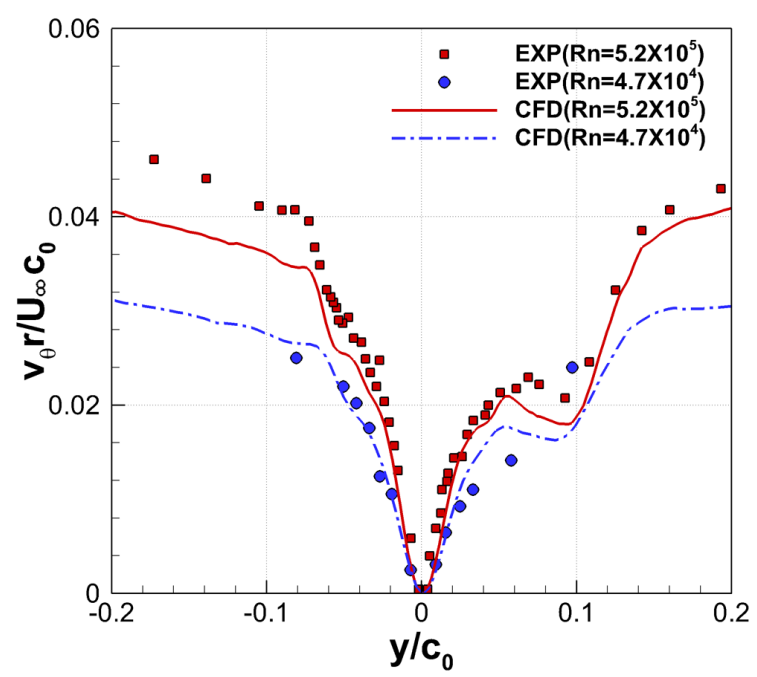

(b) Reynolds number dependency

Fig. 11 Comparison of angular momentum profile

내부에서 난류에너지 값이 상기 저자들의 연구와 같이 매우 낮은 것을 볼 수 있다. RKE 난류모형은 유동의 변형률(Strain rate)이 커 지는 영역에서 난류생성을 과도하게 예측하여 난류에너지를 높이 는 단점이 있다. 또한, RKE 모형에서는 높아진 난류에너지가 유체 의 점성과 같은 역할을 하는 난류점성(Turbulent viscosity)의 형태 로 유동의 운동량 변화에 영향을 미친다. 이는 결과적으로 보오텍 스의 강도를 감소시키는 수치감쇠의 영향으로 나타난다.

Fig. 11(a)은 난류모형 및 세 가지 격자에 따른 $x / c_{o} 1.0$ 인 위치 에서 날개 끝 보오텍스 중심에 대한 유동의 각운동량(Angular momentum)을 실험결과와 비교하고 있다. 주어진 반경들에서 이 값을 원주 방향으로 적분할 경우 날개의 순환(Circulation) 분포 를 얻을 수 있다. RSM 난류모형의 세 가지 격자계에 대해서는 실험결과와 모두 비슷한 일치를 보이고 RKE의 결과는 보오텍 스 중심에서 차이를 보이고 있다. Fig. 11(b)는Reynolds수 변화에 따른 각운동량 분포를 실험결과와 각각 비교하고 있다. 여기서, 수치해석 결과는 RSM 난류모형과 가장 조밀한 격자계를 사용 한 결과이다. 수치해석 결과는 각각의 Reynolds수에 대한 실험

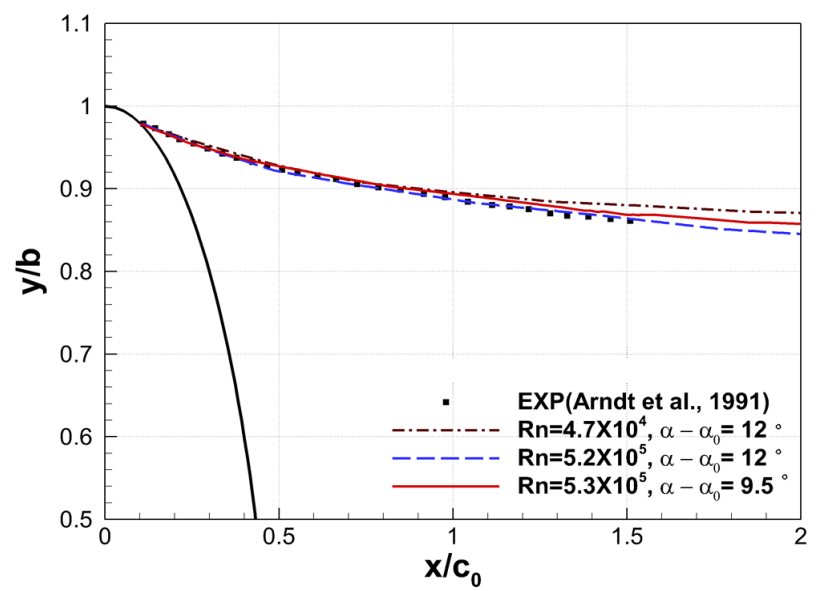

Fig. 12 Comparison of tip vortex trajectory

결과들과 만족스러운 일치를 보여주고 있다. 본 비교는 수중익 후류의 보오텍스 감김(Vortex roll-up) 현상이 점성의 영향을 크 게 받고 있음을 보여준다. 또한. 날개의 총 순환 값은 높은 Reynolds수에서 크며 날개 끝 보오텍스 캐비테이션 발생의 Reynolds수 의존성에 대한 암시를 보여준다(Arndt et al., 1991).

Fig. 12는 Reynolds수 및 타원형 수중익 입사각 변화 그리고 날개 끝 보오텍스 캐비테이션 고려한 수중익 하류의 보오텍스 궤적을 비교하고 있다. 여기서, $R_{n} 5.3 \times 10^{5}$ 그리고 입사각 $9.5^{\circ}$ 는 실험과 수치해석 모두 날개 끝 보오텍스 캐비테이션 궤적을 나 타낸다. 그리고 그림의 비교는 $y$ 축을 $x$ 보다 2.5 배 크게 확대하 여 비교하고 있다. 이미 알려진 바와 같이 날개 끝 보오텍스 궤 적은 Reynolds수와 입사각 변화 그리고 캐비테이션 발생에 따라 크게 차이가 없는 것을 볼 수 있다(Krasny, 1987; Arndt et al., 1991). 본 수치해석 결과들도 동일한 경향을 잘 보여주고 있으 며 실험결과와 좋은 일치를 보여주고 있다.

\section{3 타원형 수중익의 날개 끝 캐비테이션 해석}

본 절에서는 대상 타원형 수중익의 날개 끝 캐비테이션에 대 한 수치해석 결과를 소개한다. 수치해석은 Arndt et al.(1991)의 실험 조건을 따라 유속 $6.62 \mathrm{~m} / \mathrm{s}$ 의 Reynolds수 $5.3 \times 10^{5}$ 그리고 입 사각 $\alpha_{e f f} 9.5^{\circ}$ 인 조건에서 수행되었으며, 이때 캐비테이션수 $\sigma$ 0.58 의 조건이다. 수치격자는 앞서 설명한 동일한 세 가지 격자 계를 사용하고 RSM 난류모형과 RKE 난류모형의 결과를 비교 하였다.

Fig. 13은 실험에서 관찰된 캐비테이션과 가장 조밀한 격자계 를 사용한 수치해석 결과를 두 가지 난류모형에 대해 비교하고 있다. 여기서, 수치해석 결과의 캐비테이션은 증기 체적분율 (Vapour volume fraction) 0.5 의 값으로 그려졌다. 수치해석 결과 에서 실험과 비슷한 위치에서 캐비테이션이 발생하여 수중익 하류로 흘러가는 것을 볼 수 있으며, 여기서, 캐비테이션의 궤 적은 앞서 Fig. 12에서 실험과 비교한 결과와 동일하다. RKE 난 류모형의 결과는 실험과 RSM 모형의 결과와는 달리 캐비테이 션이 수중익 하류로 멀리 전파되지 못하고 짧은 형태를 보이고 있다. 이는 앞서 날개 끝 보오텍스 유동의 전파에 대한 난류모 형의 특성에서 설명한 바와 같이 RKE 모형의 과도한 난류점성 으로 인한 수치감쇠 영향의 결과이다. 


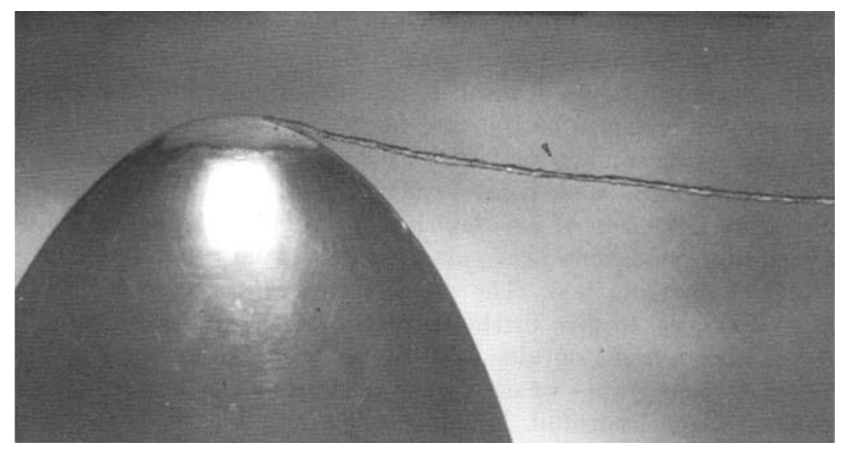

(a) EXP (Arndt et al., 1991)

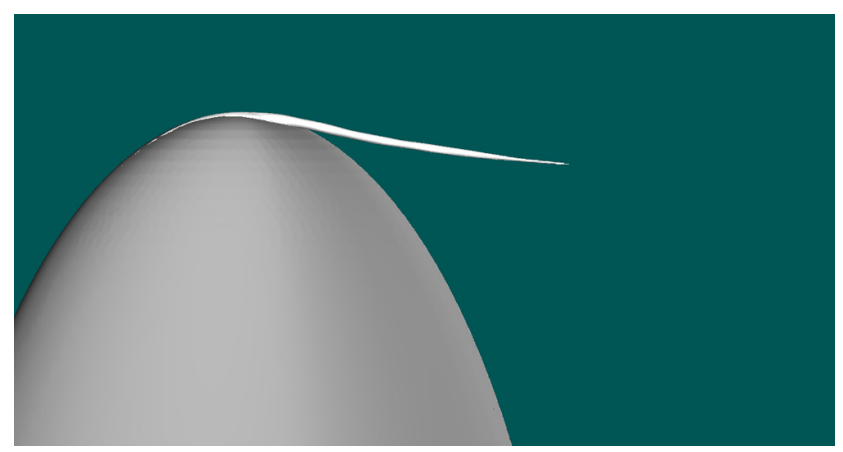

(b) RKE

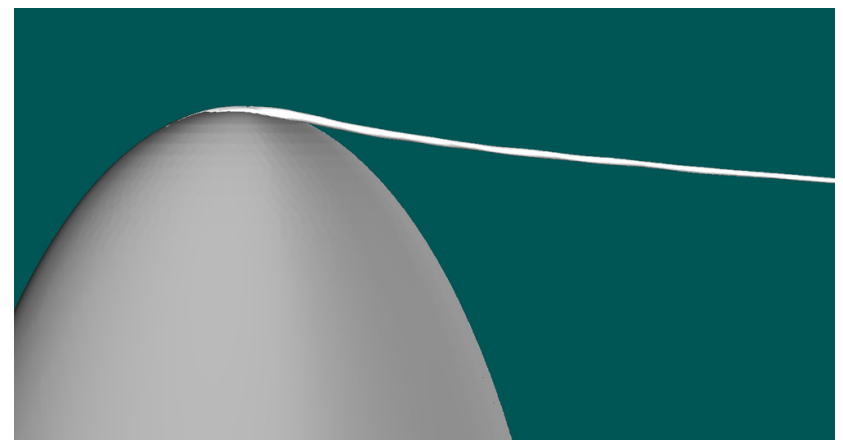

(c) RSM

Fig. 13 Comparison of tip vortex cavitation

실험과 만족스러운 일치를 보여주는 RSM 난류모형의 격자계 의존성은 Fig. 14에 나타내었다. 가장 성긴 격자계에서 캐비테 이션은 수중익 뒷날 위치 정도에서 끝나고 있고, 중간 격자계에 서는 수중익 뒷날에서 코드길이 1 배 정도 그리고 가장 조밀한 격자계에서는 코드길이 2 배 이상까지 캐비테이션이 생성되고 있다. 이러한 수중익 하류의 날개 끝 보오텍스 캐비테이션 해석 정도는 캐비테이션 유동소음 해석의 정확도를 결정하는 중요한 요소 중 하나가 된다.

Fig. 15는 조밀한 격자계에서 해석된 타원형 수중익의 날개 끝 보오텍스 캐비테이션과 그 주위 압력계수 분포를 난류모형 에 대해 비교하고 있다. 날개 끝 보오텍스 캐비테이션은 앞 절 에서 캐비테이션이 발생하지 않는 조건에서 살펴본 난류모형의 특성대로 해석된 각각의 보오텍스 내부의 낮은 압력영역을 따 라 발생하고 있다. Arndt et al.(1991)의 실험에 의하면 Case 1과 Case 2의 Reynolds수 조건에 해당하는 날개 끝 보오텍스 중심의

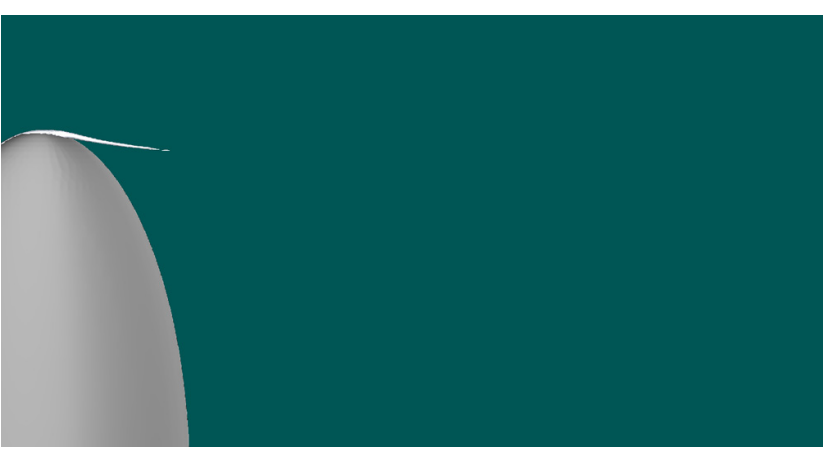

(a) Coarse grid

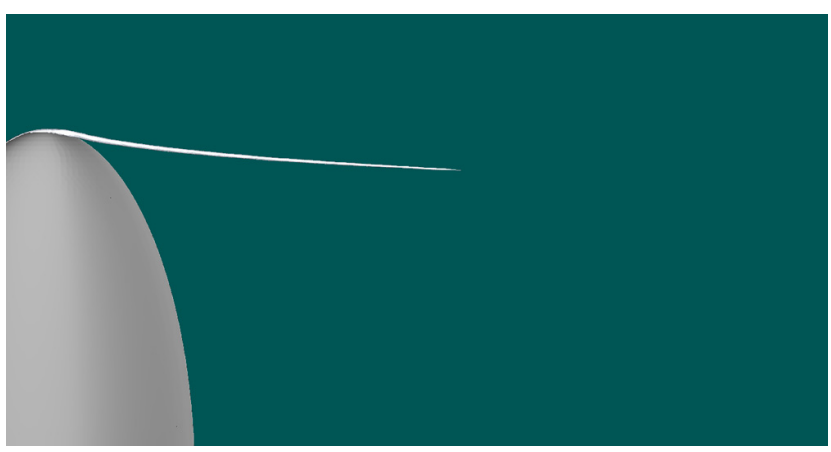

(b) Medium grid

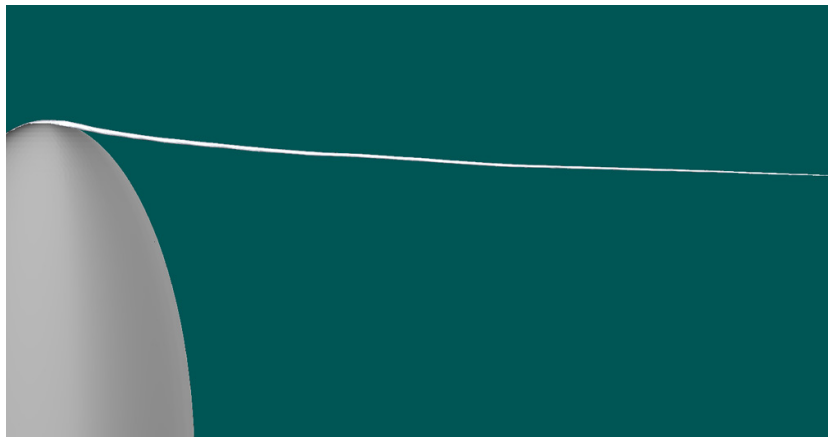

(c) Fine grid

Fig. 14 Grid dependency on tip vortex cavitation computations

회전수는 각각 $96,000 \mathrm{rpm}$ (Revolution per minute)과 220,000rpm이 며, 이러한 빠른 회전유동으로 인해 보오텍스 내부가 주위보다 낮은 압력을 가지는 것으로 해석되고 있다.

Fig. 16은 타원형 수중익의 날개 끝 주위 흡입면과 압력면을 확대하여 날개 끝 보오텍스 캐비테이션이 시작되는 영역을 각 각 보여주고 있다. 타원형 수중익이라 경계가 명확하지 않지만, 수중익 표면에서 캐비테이션의 시작은 수중익의 앞날(Leading edge)에서 날개 끝으로 이어지는 부분에서 관찰된다. 그림에서 캐비테이션은 날개 끝 주위 표면 압력이 낮은 영역이며 여기서 압력면과 흡입면 유속의 차이로 날개 끝 보오텍스가 시작되어 이후 하류로 대류되는 곳으로 판단된다.

Fig. 17은 날개 끝 보오텍스 캐비테이션과 그 주위의 $x, y$ 그 리고 $z$ 방향 유속 분포를 보여주고 있다. Fig. 17(a)의 $x$ 축 방향 속도 분포의 경우 수중익 날개 끝에 가까운 영역에서 날개 끝 보오텍스가 발달되면서 그 내부의 $x$ 축 방향 유속이 손실되는 


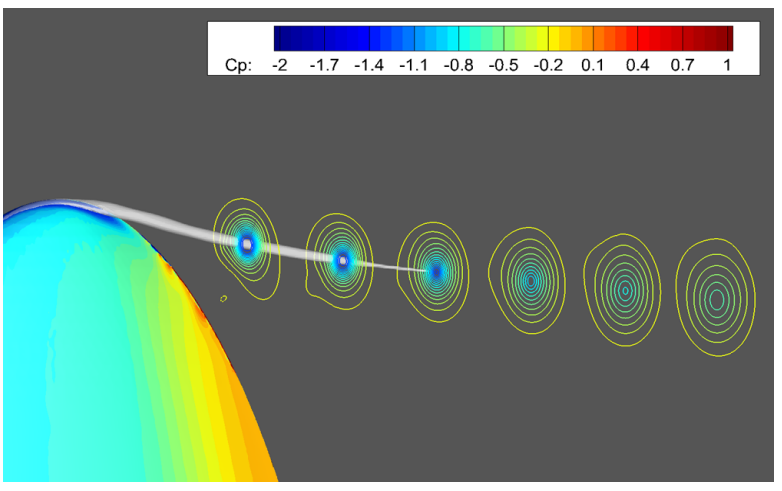

(a) RKE

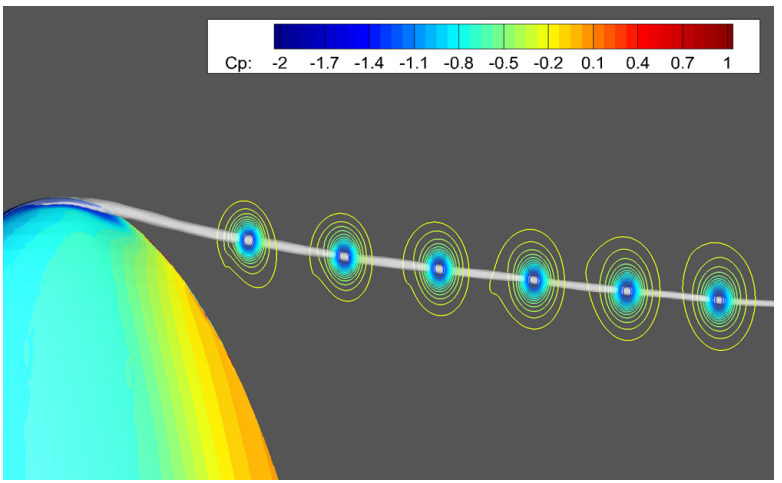

(b) RSM

Fig. 15 Comparison of tip vortex cavitation with pressure coefficient

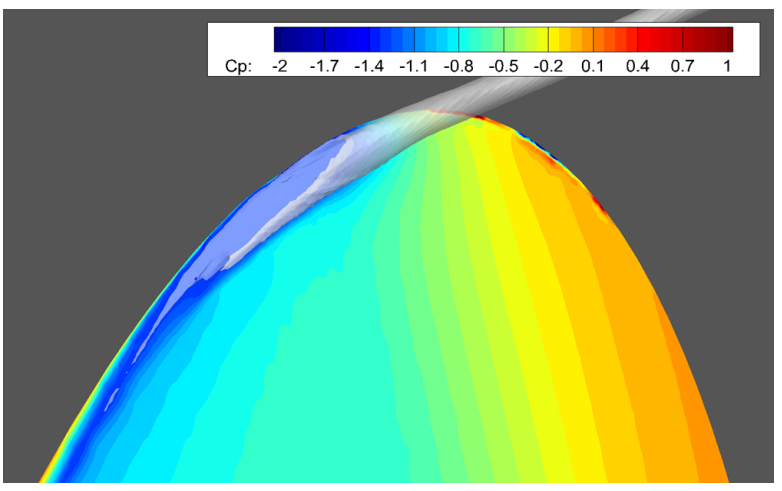

(a) Suction side

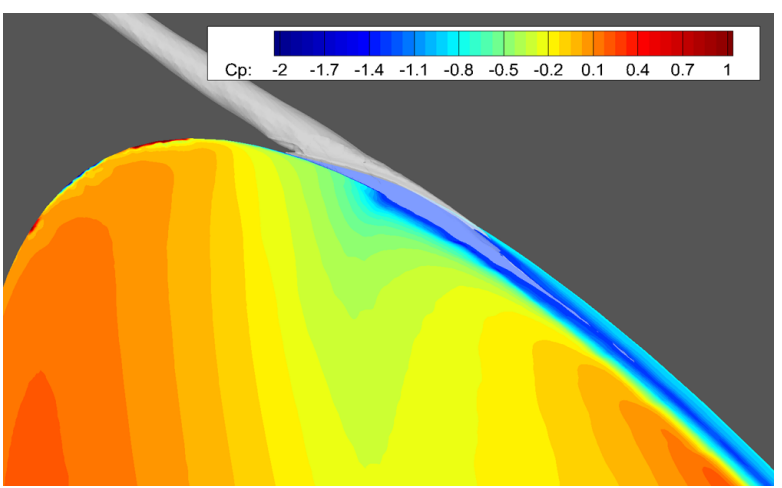

(b) Pressure side

Fig. 16 Close views of tip vortex cavitation with the pressure on the hydrofoil surface

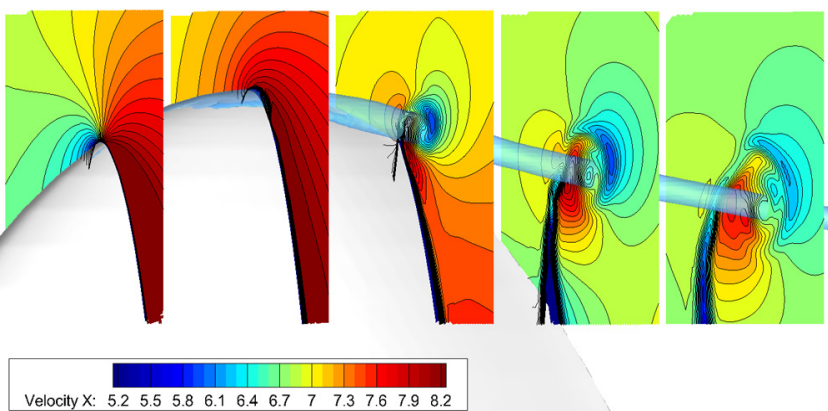

(a) $x$-velocity $(u)$
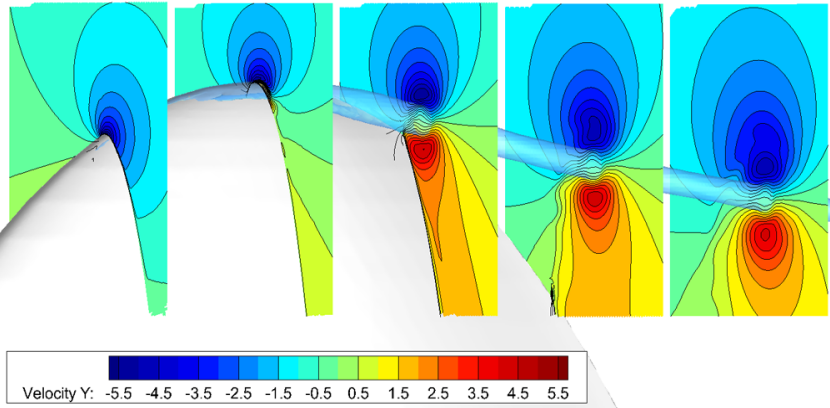

(b) $y$-velocity $(v)$

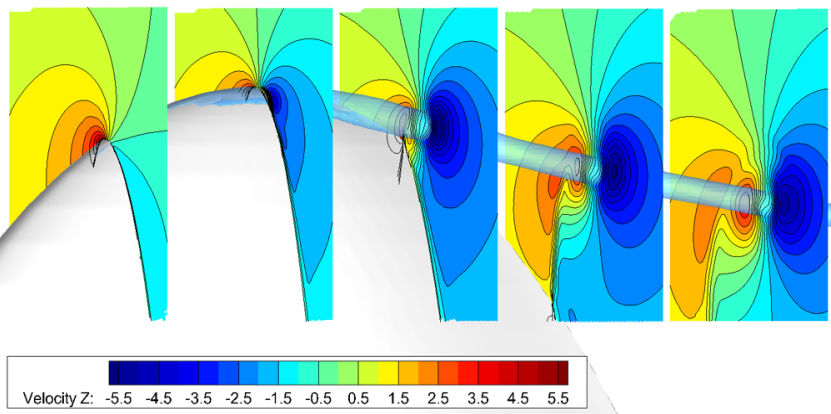

(c) $z$-velocity $(w)$

Fig. 17 Velocity components with tip vortex cavitation near the tip

과정을 볼 수 있다. $y$ 와 $z$ 방향 유속 분포에서는 주류가 날개 끝 을 통과하면서 압력면에서 흡입면으로 회전유동이 발달되어 수 중익 표면과의 상호작용은 물론 수중익의 뒷날에서 발달되는 2 차 유동과의 상호작용으로 변형하는 과정을 엿볼 수 있다. Fig. 12 에서 날개 끝 보오텍스의 궤적이 Reynolds수와 입사각 변화 그리고 날개 끝 보오텍스 캐비테이션의 영향에 크게 의존적이 지 않다는 사실을 바탕으로, 날개 끝 보오텍스 캐비테이션의 발 생으로 주위 유동의 변화는 미미한 것으로 판단된다.

\section{4. 결 론}

본 논문에서는 NACA $66_{2}-415$ 단면의 타원형 수중익에서 발생 하는 날개 끝 보오텍스와 캐비테이션 연구를 위해 RANS법을 이용한 CFD 해석 결과를 소개하였다.

수치해석을 통해 수중익 하류로 흘러가는 좁은 반경의 날개 끝 보오텍스 캐비테이션을 정확히 해석하기 위해서는 보오텍스 주위 격자 해상도를 높이고 격자 집중 영역을 하류방향으로 길 
게 확장하는 것이 필요하였다. 보다 정확한 날개 끝 보오텍스 유동의 예측을 위해서는 2 차 정확도의 수치 이산화 기법을 사 용한 본 논문과는 달리 격자 해상도를 더 증가시키고 보다 높 은 차수의 이산화 기법을 활용한 연구가 필요한 것으로 판단된 다. 그러나 한편으로 수치해석적 부담을 줄이기 위해 보다 성긴 격자계에서 유동의 해상도가 좋은 고차 난류모형을 사용하는 방법들도 연구해야할 것으로 사료된다(Wells, 2009).

$\mathrm{RKE}$ 난류모형은 날개 끝 보오텍스를 생성하는 과정에서 난 류생성을 과도하게 예측하여 보오텍스 내 난류점성에 의한 운 동량 변화를 크게 증가시켰다. 이로 인하여 수중익 하류로 갈수 록 보오텍스의 강도를 감소시키는 수치감쇠 현상이 두드러졌다. $\mathrm{RSM}$ 난류모형의 결과는 날개 끝 보오텍스가 완전히 발달되는 과정에서 발생하는 유동의 층류화 현상으로, 보오텍스 중심부 의 축방향 속도손실과 유속변화 그리고 보오텍스 내 각운동량 변화의 Reynolds수 의존성 등을 실험결과와 유사하게 잘 예측하 였다. 마지막으로 날개 끝 보오텍스 캐비테이션 CFD 해석에서 도 보오텍스 주위로 격자를 집중하고 RSM 난류모형을 사용한 경우 실험의 결과와 만족스러운 일치를 보이는 해석 결과를 얻 을 수 있었다.

향후, 본 연구를 바탕으로 함정 프로펠러 날개 끝 보오텍스 캐비테이션의 초생속도와 유동소음 해석에 대한 연구를 수행할 예정이다.

\section{후 기}

본 연구는 선박해양플랜트연구소의 '미래잠수함 저소음추진기 특화연구실'의 '미래잠수함 추진기소음 모형시험법 개발 및 $\mathrm{D} / \mathrm{B}$ 구축연구 (FS-02)' 과제(PGS3382)와 민군기술개발과제 '선박용 CPP 캐비테이션 초생선속 최적 설계기술 개발' 과제(PNS3020) 지 원으로 작성이 되었습니다.

\section{References}

Ahn, J.W., Park, Y.H., Moon, I.S., Kim, K.S., 2001. Cavitation and Noise Characteristics of High-Speed Propellers with Geometric Variations. Journal of the Society of Naval Architects of Korea, 38(3), 23-30.

Arndt, R.E.A., Arakeri, V.H., Higuchi, H., 1991. Some Observations of Tip-vortex Cavitation. Journal of Fluid Mechanics, 229, 269-289.

Choi, J.E., Chung, S.H., Lee, D.H., 2007. Cavitating Flow Characteristics around a 2-Dimensional Hydrofoil Section. Jounal of the Society of Naval Architects of Korea, 44(2), 74-82.

Dacles-Mariani, J., Kwak, D., Zilliac, G., 1999. On Numerical Errors and Turbulence Modeling in Tip Vortex Flow Prediction. International Journal for Numerical Methods in Fluids, 30(1), $65-82$.

Devenport, W.J., Rife, M.C., Liapis, S.I., Follin, G.J., 1996. The Structure and Development of a Wing-tip Vortex. Journal of
Fluid Mechanics, 312, 67-106.

Egolf, T., Wake, B., Berezin, C., 2000. Recent Rotor Wake Simulation and Modeling Studies at United Technologies Corporation. In 38th Aerospace Sciences Meeting and Exhibit, AIAA-20000115 .

Kang, T.J., Park, W.G., Jung, C.M., 2014. Cavitation Flow Analysis of Hydrofoil with Change of Angle of Attack. Jounal of Computational Fluids Engineering. 19(2), 17-23.

Kim, J.I., Park, I.R., Kim, K.S., Ahn, J.W., 2017. Numerical Analysis of Non-Cavitating and Cavitating Performance of a SVA Potsdam Propeller. Journal of the Society of Naval Architects of Korea, 54(3), 215-226.

Krasny, R., 1987, Computation of Vortex Sheet Roll-up in the Trefftz Plane. Journal of Fluid Mechanics, 184, 123-155.

Lee, C.H., Han, J.M., Kim, J.H., Ahn, B.K., 2010a. Propeller Tip Vortex Cavitation Control Using Water Injection. Journal of the Society of Naval Architects of Korea, 47(6), 770-775.

Lee, P.H., Ahn, B.K., Lee, J.H., Lee, C.S., 2010b. Experimental Study on Underwater Radiated Noise Characteristics of the Type of Propeller Cavitations. Proceedings of the SNAK Conference, 1003-1013.

Lee, S.J., Seo, J., Han, J., 2007. Experimental Study on the Cavitation Noise of a Hydrofoil. Journal of the Society of Naval Architects of Korea, 44(2), 111-118.

Park, K.K., 2004. Numerical Analysis of Tip Vortex Cavitation Behavior and Noise(Ph.D. Thesis). University of Seoul, Korea.

Park, K.K., Seol, H.S., Lee, S.G., 2006. Numerical Analysis of Tip Vortex Cavitation Behavior and Noise on Hydrofoil using Dissipation Vortex Model and Bubble Theory. Jounal of the Society of Naval Architects of Korea. 43(2), 177-185.

Peng, X.X., Xu, L.H., Liu, Y.W., Zhang, G.P., Cao, Y.T., Hong, F.W., Yan, K., 2017. Experimental Measurement of Tip Vortex Flow Field with/without Cavitation in an Elliptic Hydrofoil. Journal of Hydrodynamics. 29(6), 939-953.

Ragab, S., Sreedhar, M., 1995. Numerical Simulations of Vortices with Axial Velocity Deficits. Physics of Fluids, 7(3), 549-558.

Sauer, J., 2000. Instationär Kavitierende Strömungen-Ein Neues Modell, Basierend auf Front Capturing (VoF) und Blasendynamik (Ph.D. Thesis). Universität Karlsruhe, Germany.

Seol, H.S., Lee, S.G., Pyo, S.W., Suh, J.C., 2004. Numerical Analysis of Underwater Propeller Noise. Journal of the Society of Naval Architects of Korea, 41(2), 33-46.

Siemens, 2016. STAR-CCM+ User Guide. Version 11.06.

Zeman, O., 1995. The Persistence of Trailing Vortices: A Modeling Study. Physics of Fluids, 7, 135-143.

Wells, J., 2009. Effects of Turbulence Modeling on RANS Simulations of Tip Vortices(Master's thesis). Virginia Polytechnic Institute and State University. 